\title{
De impact van opvoedingsstress en depressieve symptomen op de ouder-kind communicatie van gehuwde moeders en vaders.
}

\author{
Koen Ponnet ${ }^{1}$ (D), Inge Pasteels ${ }^{1}$ (D) Kim Bastaits $^{1}$ (D), \\ Griet Vanderheyden ${ }^{1}$, Dimitri Mortelmans ${ }^{1}$ \\ ${ }^{1}$ Universiteit Antwerpen
}

Abstract

In deze bijdrage gaan we na in welke mate opvoedingsstress en depressieve symptomen van gehuwde moeders en vaders een invloed hebben op de eigen communicatie met het kind (actoreffecten) en op de communicatie van de andere ouder met het kind (partnereffecten). Gegevens uit het project "Scheiding in Vlaanderen" van 196 niet-gescheiden gezinnen werden geanalyseerd, waarbij gehuwde moeders en vaders hun eigen opvoedingsstress en depressieve symptomen beoordeelden, en waarbij de ouder-kind communicatie door zowel het kind als de ouders beoordeeld werd .

Structurele vergelijkingsmodellen tonen aan dat zelfgerapporteerde opvoedingsstress de eigen ouder-kind communicatie beïnvloedt (actoreffect), terwijl zelfgerapporteerde depressieve symptomen een impact hebben op de ouder-kind communicatie van de andere ouder (partnereffect). Deze effecten zijn even sterk voor moeders en vaders: de samenhang tussen opvoedingsstress en depressieve symptomen enerzijds en ouder-kind communicatie anderzijds is dus genderneutraal.

De resultaten hebben implicaties voor toekomstig onderzoek maar ook voor deskundigen. In toekomstige studies over ouder-kind relaties moeten bij voorkeur zowel vaders als moeders betrokken worden. Ook opvoedingsondersteunende diensten moeten beide ouders in hun vizier nemen ongeacht of de hulpvraag van een van beide ouders komt. Partnereffecten geven immers aan dat zelfs milde vormen van depressieve symptomen van de ene ouder een impact kunnen hebben op de ouder-kind communicatie van de andere ouder.

\section{INLEIDING}

Ouders zijn onderhevig aan verschillende vormen van stress: stress op het werk, in hun relatie, in het dagelijkse leven of stress met betrekking tot het opvoeden van kinderen. Het is geweten dat deze verschillende vormen van stress een invloed hebben op de ouderkind relatie en op de manier waarop ouders hun kinderen opvoeden (Belsky, 1984). Vol- gens de familiesysteemtheorie kunnen individuele gedragingen pas werkelijk begrepen worden als we rekening houden met de context van de relaties en moet onderzoek naar de relaties tussen ouders en kinderen bijgevolg rekening houden met zoveel mogelijk leden van de familie (Bronfenbrenner, 1989). Het merendeel van de huidige studies naar de ouder-kind relaties besteedt echter voornamelijk aandacht aan de relatie moeder-kind. Dit komt enerzijds omdat moeders van ouds- 
her de meest centrale rol op zich nemen met betrekking tot de opvoedingstaken, en anderzijds omdat vaders zeer moeilijk te betrekken zijn in onderzoek rond opvoeding (Mitchell et al., 2007; Phares, Duhig, \& Watkins, 2002). Niettegenstaande mannen meer en meer opvoedingstaken op zich nemen, is er weinig geweten over hun rol als vader (Lamb, 2010).

De schaarse studies naar de opvoedingsgedragingen van vaders en naar vader-kind relaties onderzoeken bovendien meestal vaders en moeders in aparte analysemodellen. Enerzijds is het hierdoor niet mogelijk om na te gaan in welke mate de opvoedingsgedragingen van vaders en moeders binnen eenzelfde gezin van elkaar verschillen. Anderzijds kunnen we ervan uitgaan dat het opvoedingsgedrag van vaders niet alleen bepaald wordt door hun eigen stress (actoreffect), maar ook door de stress van hun partner (partnereffect), en omgekeerd- zal het opvoedingsgedrag van moeders ook beïnvloed worden door zowel de eigen stress als de stress van de vader. $\mathrm{Er}$ is met andere woorden nood aan sociaalpsychologisch onderzoek waarbij beide ouders binnen eenzelfde gezin bevraagd worden.

In deze studie betrekken we beide ouders en gaan we na in welke mate twee specifieke bronnen van stress (opvoedingsstress en depressieve symptomen) een invloed hebben op de moeder-kind en vader-kind relatie. Terwijl opvoedingsstress kan beschouwd worden als het hebben van negatieve gevoelens ten aanzien van zichzelf en het kind (Deater-Deckard, 1998), kunnen depressieve symptomen beschouwd worden als negatieve gevoelens ten aanzien van zichzelf (Goodman \& Gotlib, 1999). Sommige onderzoekers beweren dat de vader-kind relatie meer gevoelig is voor stress dan de moeder-kind relatie (Cummings e.a., 2004). Een mogelijke verklaring voor deze verhoogde kwetsbaarheid is dat mannen moeilijker dan vrouwen een onderscheid kunnen maken tussen hun rol als vader en hun rol in andere levensdomeinen, zoals deze als echtgenoot, waardoor het vaderschap gevoeliger is voor stress die voortspruit uit andere levensdomeinen (Coiry \& Emmery, 1998). Het weinige onderzoek naar de verhoogde kwetsbaarheid van vaderschap en vader-kind rela-

\section{Over het onderzoek}

\section{Scheiding in Vlaanderen (SiV)}

SiV-data zijn afkomstig van het onderzoek "Scheiding in Vlaanderen". In dit onderzoek werd via een interview informatie verzameld bij beide partners van eerste huwelijken die afgesloten zijn tussen 1971 en 2008 en intussen al dan niet ontbonden zijn. Ook een kind, een ouder en een eventuele nieuwe partner van deze personen werden indien mogelijk bevraagd. Zij kregen een schriftelijke vragenlijst of websurvey aangeboden. De gegevens zijn verzameld in de periode van september 2009 tot december 2010.
12110 van alle 26376 gecontacteerde personen konden bevraagd worden wat een totale respons van $46 \%$ oplevert voor deze multi-actorstudie over huwelijk en echtscheiding. Gedetailleerde informatie over dit onderzoek en deze dataverzameling vindt $u$ op www.scheidinginvlaanderen.be en in het boek: Mortelmans Dimitri, Pasteels Inge, Bracke Piet, Matthijs Koen, Van Bavel Jan, Van Peer Christine (2011) Scheiding in Vlaanderen. ISBN 978-90-334-85862 - Leuven: Acco, 355 p. 
ties levert niettemin gemengde resultaten op en moet met enige voorzichtigheid geïnterpreteerd worden. De analyses met betrekking tot moeder-vader verschillen zijn zelden gebaseerd op vaders en moeders binnen eenzelfde gezin (Cummings e.a., 2004, 2010). Zoals reeds vermeld is het aangewezen om te focussen op vaders en moeders binnen eenzelfde gezin, zodanig dat we rekening kunnen houden met de onderlinge afhankelijkheid tussen beiden (Kenny, Kashy, \& Cook, 2006).

\section{OPVOEDINGSSTRESS EN DEPRESSIEVE SYMPTOMEN ALS DETERMINANTEN VAN DE OUDER-KIND COMMUNICATIE}

Studies hebben aangetoond dat opvoedingsstress en ouderlijke depressieve symptomen aanleiding kunnen geven tot probleemgedrag bij jongeren (Cummings, Keller, \& Davies, 2005; Goodman e. a., 2011). Ouder-kind relaties die gekenmerkt worden door open communicatie worden beschouwd als mechanismen die deze negatieve effecten kunnen verzachten of voorkomen. Over het algemeen zijn familiale relaties hechter wanneer de ouderkind communicatie meer open is, en een open ouder-kind communicatie lijkt een positieve invloed te hebben op de ontwikkeling van jongeren, met onder andere minder depressieve symptomen, minder problematisch gedrag, een hoger zelfvertrouwen en meer levenstevredenheid bij de jongeren (Ackard e. a., 2006; Riesch, Anderson, \& Krueger, 2006). Alhoewel de samenhang tussen ouder-kind relaties en het gedrag van kinderen en jongeren behoorlijk onderzocht is, is er nog maar weinig onderzoek gedaan naar de determinanten van de ouder-kind communicatie. Een open ouder-kind communicatie is nochtans een belangrijk kenmerk van ouder-kind relaties (Jackson, Bijstra, Oostra, \& Bosma, 1998).

In deze paper focussen we op opvoedingsstress en depressieve symptomen, twee determinanten van ouder-kind communicatie die zelden tegelijkertijd zijn onderzocht. Hierna beschrijven we kort aan de hand van de literatuur hoe beide determinanten een invloed kunnen hebben op de ouder-kind communicatie.

\subsection{OPVOEDINGSSTRESS EN OUDER-KIND COMMUNICATIE}

Stress is een multi-dimensioneel construct dat geoperationaliseerd kan worden op verschillende manieren, afhankelijk van de bron van de stressor. Opvoedingsstress is een specifieke vorm van stress, die verwijst naar gevoelens die ouders ervaren wanneer de opvoedingsvereisten de persoonlijke mogelijkheden te boven gaan, waardoor men niet meer kan voldoen aan deze opvoedingsvereisten. In zekere mate ervaren alle ouders soms opvoedingsstress, maar de manier waarop ze omgaan met deze stress varieert (Crnic \& Low, 2002).

Verschillende studies suggereren dat opvoedingsstress de ouder-kind relatie, waarvan communicatie een deel uitmaakt, op een minder positieve manier beïnvloedt. Moeders die veel opvoedingsstress ervaren, vertonen meer controle en minder warmte of steun in hun opvoedingsstijl, en zijn minder betrokken bij hun kinderen (Crnic \& Low, 2002). Seginer en collega's (2002) vonden een negatief verband tussen opvoedingsstress en positieve ouderadolescent relaties, waarbij open ouderadolescent communicatie deel uitmaakte van dit concept. Niettemin is de mate waarin op- 
voedingsstress de communicatie van beide ouders met het kind beïnvloedt, niet helemaal duidelijk (Crnic, Gaze, \& Hoffman, 2005). Vooral over vaders is er weinig geweten. Aangezien vaders steeds meer beschouwd worden als evenwaardige opvoeders (in relatie tot moeders) is het dan ook interessant om na te gaan of de impact van opvoedingsstress op de ouder-kind communicatie verschillend is voor moeders en vaders en of er een relatie is tussen stress van de ene op de andere ouder .

\subsection{DEPRESSIEVE SYMPTOMEN EN OUDER- KIND COMMUNICATIE}

Alhoewel er een overlap bestaat tussen klinisch gediagnosticeerde depressie (APA, DSMIV-TR) en depressieve symptomen, benadrukken we dat de focus in deze studie enkel op de meer algemeen aanwezige depressieve symptomen ligt. Uitgebreid onderzoek toont aan dat depressieve symptomen van moeders een impact hebben op de hele familie (Gotlib \& Goodman, 1999). Voornamelijk kinderen lijken kwetsbaar voor depressieve symptomen van hun moeder. Ze vertonen bijvoorbeeld zelf meer depressieve gevoelens en presteren minder goed op school dan kinderen waarvan de moeder geen depressieve symptomen vertoont (Goodman, 2007). Depressieve symptomen van moeders worden verder gelinkt aan meer negatieve (bv. meer geïrriteerd zijn, vijandigheid) en minder positieve (bv. leuke dingen doen) interacties met kinderen, een minder warme en een meer controlerende opvoeding. Niettegenstaande deze duidelijke resultaten, is er nog maar weinig onderzoek verricht naar depressieve symptomen bij vaders. Enkele schaarse studies (zie Wilson en Durbin, 2010) suggereren dat de communicatie tussen vader en kind evenzeer beïnvloed wordt door zijn zelfgerapporteerde depressieve symptomen als dat de communicatie tussen moeder en kind beïnvloed wordt door haar zelfgerapporteerde depressieve symptomen (actoreffecten).

Onderzoek naar zowel actor- en partnereffecten is echter schaars. Voor zover ons bekend zijn er slechts twee studies die zowel actor- en partner-effecten onderzoeken met betrekking tot mogelijke effecten tussen depressieve symptomen en ouder-kind relaties. Het eerste onderzoek is van Nelson en collega's (2009). Dit onderzoek focust niet zozeer op de invloed van depressieve symptomen op de ouder-kind communicatie, maar wel op de invloed van depressieve symptomen op de ondersteunende en niet-ondersteunende technieken die ouders gebruiken bij het aanleren van emoties aan hun kinderen. Nelson e.a. (2009) vonden enkel partner-effecten tussen depressieve symptomen en de ouderlijke reacties, terwijl de actoreffecten niet significant waren. Het tweede onderzoek werd uitgevoerd door Malmberg en Flouri (2011) die actor- en partner-effecten onderzochten tussen depressieve symptomen en ouder-kind relaties. In tegenstelling tot de bevindingen van Nelson e.a. (2009) vonden deze onderzoekers zowel actor- als partnereffecten. Beide studies konden echter niet bevestigen of de sterkte van de paden tussen depressieve symptomen en ouderlijke reacties (Nelson e.a., 2009) of tussen depressieve symptomen en ouder-kindrelaties (Malmberg en Flouri, 2011) verschillend zijn voor moeders en vaders. Deze paper bouwt verder op beide onderzoeken en gaat na in welke mater er actor- en partnereffecten aanwezig zijn tussen opvoedingsstress en depressieve symptomen enerzijds en open ou 
Figuur 1. Conceptueel model

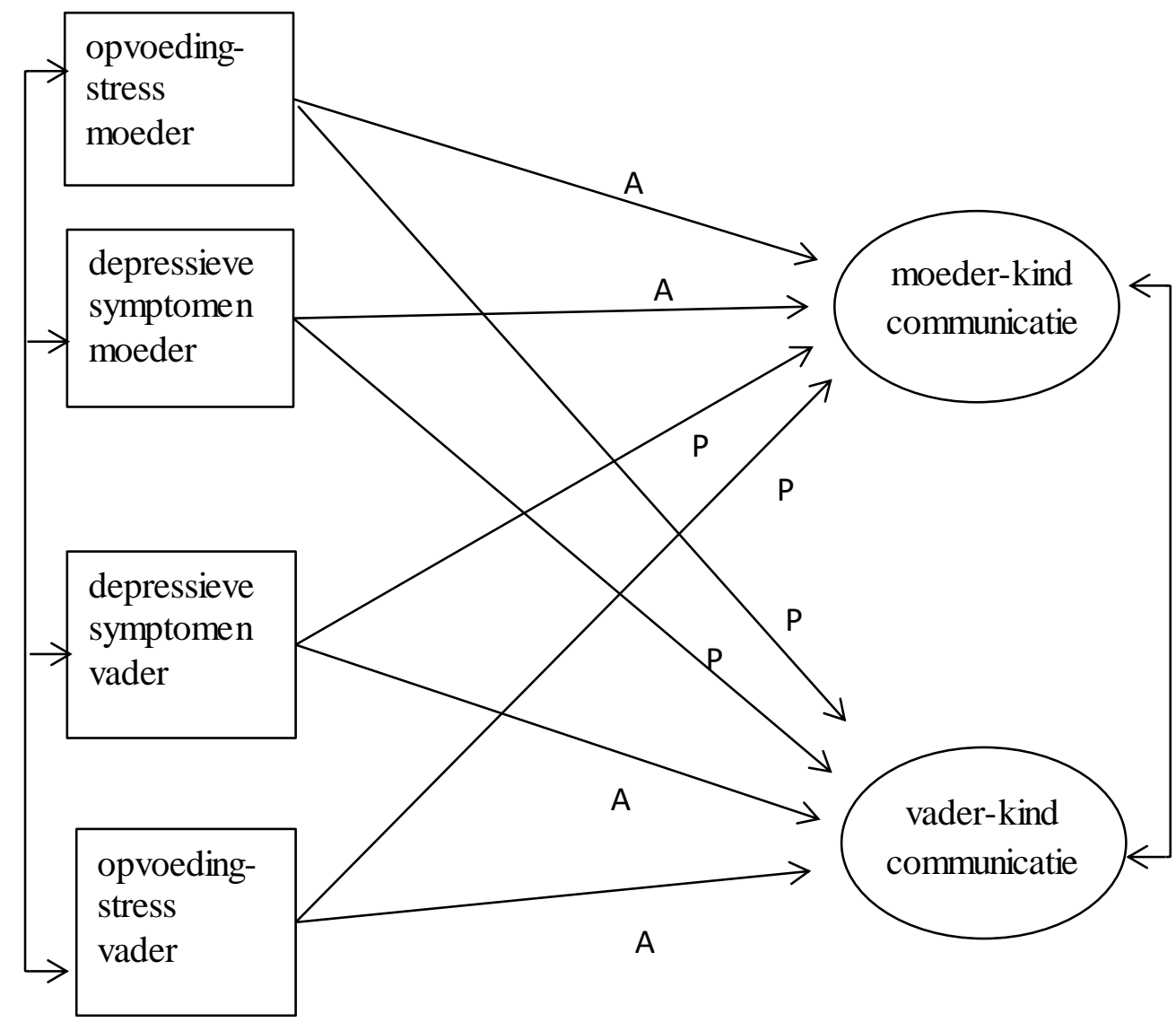

Nota: $\mathrm{A}=$ Actoreffect, $\mathrm{P}=$ Partner-effect

der-kind communicatie anderzijds (zie Figuur 1).

\section{HYPOTHESEN}

Op basis van het vooropgestelde model (zie Figuur 1) behandelen we volgende hypothesen. Ten eerste gaan we na of opvoedingsstress en depressieve symptomen die een ouder ervaart een invloed hebben op zijn/haar eigen ouder-kind communicatie (actoreffecten), maar ook of deze een invloed hebben op de ouder-kind communicatie van de partner (partnereffecten). Terwijl opvoedingsstress een kenmerk is dat voortvloeit uit de ouderkindrelatie, situeren depressieve symptomen zich op het individuele niveau. Op basis van de literatuur (Crnic \& Low, 2002; Seginer e. a., 2002; Wilson \& Durbin, 2010) verwachten we significante actoreffecten voor moeders en vaders, waarbij meer opvoedingsstress en 
depressieve gevoelens leiden tot minder eigen open ouder-kind communicatie. Overeenkomstig verwachten we dat meer opvoedingsstress en depressieve gevoelens van de ene ouder leiden tot minder open communicatie tussen het kind en de andere ouder.

Ten tweede onderzoeken we in welke mate deze actor- en partnereffecten verschillend zijn voor moeders en vaders. We onderzoeken met andere woorden of vaders gevoeliger zijn voor stress dan moeders. Gebaseerd op andere actor/partnerstudies met ouderlijke reacties (Nelson e.a., 2009) en ouder-kind relaties (Malmberg \& Flouri, 2011) als uitkomstvariabele, verwachten we geen geslachtsverschillen.

\section{Methode}

\subsection{DATA}

De onderzoeksgegevens zijn een extractie uit het databestand van "Scheiding in Vlaanderen". Gehuwde partners met een kind tussen 10 en 18 jaar werden geselecteerd $(n=196)$. Moeders en vaders beoordeelden hun opvoedingsstress en depressieve symptomen, terwijl beide ouders en hun kind over de open ouderkind communicatie rapporteerden.

De gemiddelde leeftijd van de kinderen is 14 jaar, $48 \%$ zijn jongens en $52 \%$ zijn meisjes. De gemiddelde leeftijd van de jongens verschilt niet van deze van de meisjes. De gemiddelde leeftijd van de vaders is 44 jaar en deze van de moeders is 43 jaar. Een paarsgewijze vergelijking toont aan dat vaders significant ouder zijn dan moeders, $t(195)=-6.98, p<.001$. Het opleidingsniveau van vaders en moeders is ook significant verschillend, $\chi 2(4)=38.1 p<.001$, met $7 \%$ moeders en $12 \%$ vaders zonder of lager onderwijs als hoogste diploma, 39\% moeders en $38 \%$ vaders met secundair onderwijs als hoogst behaalde diploma, en $54 \%$ moeders en $51 \%$ vaders die drie jaar of meer hoger onderwijs behaalden als hoogste diploma.

\subsection{SCHALEN}

Opvoedingsstress werd gemeten aan de hand van drie items (Gerris e.a., 1992). Elk van deze items meet de mate waarin de ouders het opvoeden van kinderen als een last ervaren. Moeders en vaders beantwoordden volgende drie items op een 7-puntenschaal ( $1=$ helemaal niet akkoord, 7=helemaal akkoord): "Ik heb veel meer problemen met het grootbrengen van mijn kind dan ik verwacht had", "Mijn kind opvoeden is moeilijker dan ik verwacht had", en "Het opvoeden van mijn kind stelt me nogal eens voor problemen". Confirmatorische factoranalyses toonden aan dat vaders en moeders deze items consistent beantwoordden en deze set van antwoorden als een adequate maat voor opvoedingsstress kan beschouwd worden. De opvoedingsstress van moeder correleert met deze van de vader binnen het gezin. Cronbach's alpha was .86 voor vaders en .85 voor moeders.

Depressieve symptomen werden gemeten met de acht itemschaal CES-D8 (Van de Velde, Bracke, \& Levecque, 2010), hetgeen een verkorte versie is van de Center for Epidemiological Studies Depression Scale of CES-D (Radloff, 1977). Moeders en vaders werden gevraagd hoe ze zich de afgelopen week voelden of gedroegen (bv. voelde zich eenzaam, voelde zich droevig, sliep slecht, ...). De items worden gescoord op een 4-punten Likertschaal $(1=$ 
zelden of niet, 4 = vaak of bijna altijd). Confirmatorische factoranalyses toonden aan dat één item ("sliep slecht") de consistentie in de antwoordpatronen eerder verstoorde. Een maat waarbij dit item niet in rekening werd gebracht, bleek beter om depressieve gevoelens te meten en kreeg dan ook de voorkeur in de verdere analyse. Cronbach's alpha was .71 voor vaders en .82 voor moeders.

Open ouder-kind communicatie werd gemeten met de Open Familie Communicatie Schaal (Gerris et al., 1992), hetgeen een subschaal is van de Parent-Adolescent Communicatie Scale van Olson (Barnes \& Olson, 1985). Beide ouders en het kind beantwoordden telkens vier vragen op een 7-puntenschaal (van $1=$ helemaal niet akkoord tot 7 = helemaal akkoord). Deze vragen waren: "Ik vind het gemakkelijk om met mijn moeder over problemen te praten" (moeder-kind communicatie door kind gerapporteerd), "Ik vind het gemakkelijk om met mijn kind over zijn/haar problemen te praten" (ouder-kind communicatie door moeder/vader gerapporteerd), "Het is gemakkelijk voor me om tegenover mijn moeder mijn ware gevoelens te uiten" (moeder-kind communicatie door kind gerapporteerd), en "Het is gemakkelijk voor mijn kind om tegenover mij zijn/haar ware gevoelens te uiten" (ouder-kind communicatie door moeder/vader gerapporteerd). Betrouwbaarheidsscores voor moederkind communicatie (gerapporteerd door moeder $\alpha=.83$ en kind $\alpha=.83$ ) en vader-kind communicatie (gerapporteerd door vader $\alpha=$ .85 en kind $\alpha=.84$ ) zijn hoog, wat opnieuw wijst op consistente antwoordpatronen en dus een adequate meting. Uit analyses blijkt verder dat moeders hun communicatie met het kind significant meer open vinden dan vaders, en -overeenkomstig- dat kinderen de moeder- kind communicatie meer open beschouwen dan de vader-kind communicatie. De moederkind en vader-kind communicatie correleren met elkaar.

Om na te gaan welke socio-demografische variabelen als covariaten in de analyses opgenomen moeten worden, werd gekeken naar de relatie tussen leeftijd en geslacht van het kind en leeftijd en opleidingsniveau van de ouders enerzijds en de uitkomstvariabelen anderzijds. Leeftijd en opleidingsniveau van de ouders waren niet significant gerelateerd met de ouder-kind communicatie. Leeftijd van het kind was significant geassocieerd met moederkind communicatie, alsook met vader-kind communicatie. Geslacht van het kind was significant geassocieerd met moeder-kind communicatie: meisjes gaven een meer open moeder-kind communicatie aan dan jongens. Aangezien de steekproef te klein was om jongens en meisjes apart te analyseren, werd het geslacht opgenomen als covariaat in het model.

\section{Resultaten}

Figuur 2 toont het geschatte model. We vonden significante actoreffecten tussen opvoedingsstress en zowel de moeder-kind als de 


\section{Figuur 2. Geschatte model}

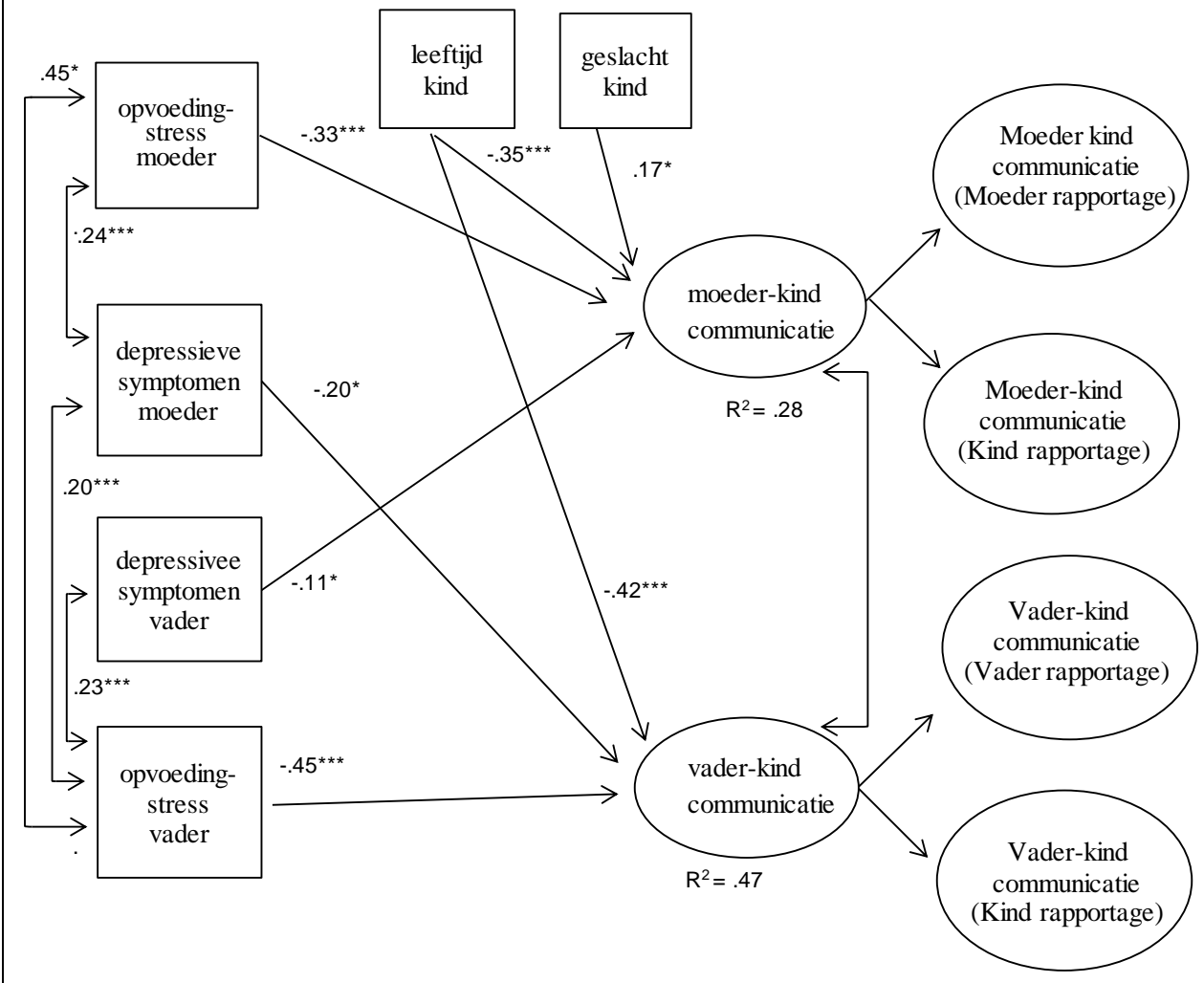

Nota: Enkel de significante paden worden getoond, met gestandaardiseerde waarden.

$* p<.05, * * * p<.001$.

vader-kind communicatie, waarbij meer opvoedingsstress aanleiding gaf tot minder open communicatie.

Verdere analyses tonen aan dat deze effecten even sterk zijn voor moeders en vaders. Er werden geen partnereffecten gevonden tussen opvoedingsstress en open ouder-kind communicatie. Verder vonden we significante partnereffecten tussen depressieve symptomen en zowel moeder-kind als vader-kind communicatie, waarbij meer depressieve symptomen van de partner resulteerden in een minder open ouder-kind communicatie. Bijkomende analyses toonden aan en dat deze partnereffecten gelijk waren voor moeders en vaders. 


\section{Discussie}

De laatste decennia is er steeds meer aandacht voor de rol van de vader in het gezin. Deze verhoogde aandacht komt echter niet altijd tot uitdrukking in onderzoek naar opvoeding en ouder-kind relaties. In ons onderzoek zijn zowel moeders als vaders betrokken, en gingen we na (a) of opvoedingsstress en depressieve symptomen die een ouder ervaart een invloed hebben op zijn/haar eigen ouderkind communicatie (actoreffect) en op de manier waarop de partner met de kinderen communiceert (partnereffect); en (b) in welke mate deze actor- en partnereffecten verschillend zijn voor moeders en vaders.

Onze resultaten tonen aan dat er sprake is van zowel actor- als partnereffecten, afhankelijk van de bron van stress. We vonden significante actoreffecten van opvoedingsstress op de open ouder-kind communicatie, waarbij meer opvoedingsstress aanleiding geeft tot minder open communicatie tussen ouders en kind. Verder vonden we partnereffecten van depressieve symptomen op de ouder-kind communicatie, waarbij meer depressieve symptomen van de ene ouder ervoor zorgen dat de andere ouder minder openlijk communiceert met het kind. In tegenstelling tot onze verwachting, vonden we geen actoreffecten van depressieve symptomen van moeder noch van vader op de eigen ouder-kind communicatie. In zekere zin komen deze resultaten overeen met deze uit het onderzoek van Nelson en collega's (2009), die ook geen significante actoreffecten vonden tussen depressieve symptomen en de ouderlijke reacties op de emoties van kinderen. Een mogelijke verklaring voor deze bevindingen is het verschillend niveau waarop opvoedingsstress en depres- sieve gevoelens zich situeren. Opvoedingsstress situeert zich op het ouder-kind niveau en reflecteert de mate waarin ouders het opvoeden van kinderen als een last beschouwen. Opvoedingsstress heeft bijgevolg betrekking op zowel ouder als kind, waardoor de actoreffecten van deze vorm van stress meer prominent aanwezig zijn op de ouder-kind relatie. Depressieve symptomen zijn daarentegen negatieve gevoelens ten aanzien van zichzelf (Goodman \& Gotlib, 1999), waardoor ze misschien minder snel de communicatie met derden, hier het kind, beïnvloeden. Alhoewel de communicatieschaal in deze bijdrage een algemene communicatieschaal is, kunnen we aannemen dat ouders en kinderen gemakkelijker met elkaar spreken over opvoedingsstress dan over depressieve symptomen. Hierdoor is het mogelijk dat de open ouder-kind communicatie meer beïnvloed wordt door de depressieve symptomen van de partner, dan door de eigen depressieve symptomen. Anders gezegd: terwijl het voor een moeder misschien moeilijk is om met haar kind te praten over haar persoonlijke depressieve symptomen, kan het voor een moeder misschien gemakkelijker zijn om te praten met haar kind over de depressieve symptomen van de vader. Om deze mogelijke verklaring verder te onderzoeken is het nodig om een communicatieschaal af te nemen bij ouders en jongeren die specifiek peilt naar communicatie rond opvoeding, stress en depressieve symptomen.

De tweede onderzoeksvraag betrof verschillen tussen vaders en moeders. We vonden geen verschillende effecten van opvoedingsstress en depressieve symptomen voor vaders en moeders. De vader-kind communicatie is dus niet kwetsbaarder voor stress en depressieve symptomen dan deze van de moeders, het- 
geen overeenkomt met ander onderzoek waarbij zowel vaders als moeders werden betrokken (Malmberg \& Flouri, 2011; Nelson e.a., 2009).

Deze studie is onderhevig aan een aantal beperkingen. Ten eerste maakt deze studie geen gebruik van longitudinale data. We veronderstellen dat opvoedingsstress en depressieve symptomen de open ouder-kind communicatie beïnvloeden, maar door het gebruik van cross-sectionele data kunnen wederkerige relaties tussen opvoedingsstress, depressieve symptomen en open ouder-kind communicatie niet uitgesloten worden. Ten tweede is het door de beperkte grootte van de steekproef niet mogelijk om modererende effecten van het geslacht en de leeftijd van het kind in rekening te brengen. Niettegenstaande Barnes \& Olson (1986) geen geslachtsverschillen vonden in de perceptie van jongens en meisjes omtrent de communicatie met hun moeders en vaders, bestaat er enige evidentie dat jongens en meisjes op een verschillende manier met hun ouders communiceren en een voorkeur hebben met welke ouder ze liefst communiceren. Zo vonden Jackson en collega's (1998) dat jongens de communicatie met hun vader meer prefereerden dan meisjes. Evenzo focussen we in deze studie op adolescenten met variërende leeftijd. We kunnen aannemen dat de ouder-kind communicatie en opvoeding verschillend is voor kinderen van pakweg 12 jaar, vergeleken met kinderen van 17 jaar. Naarmate jonge kinderen opgroeien hanteren ouders eerder een meer adviserende stijl (Reitz, Dekovic, Meijer, \& Engels, 2006). In toekomstige studies is het dus aangewezen om zowel leeftijd als geslacht van het kind als modererende variabele op te nemen. Tenslotte focussen we in deze studie op op- voedingsstress en depressieve gevoelens als determinanten van ouder-kind communicatie, zonder rekening te houden met bepaalde beschermende factoren die ouders bezitten. Sommige ouders zijn meer veerkrachtig dan andere ouders, en naarmate ouders zich meer competent voelen met betrekking tot de opvoeding hebben ze een meer open ouder-kind relatie (Ohan, Leung, \& Johnston, 2000). Dyadisch onderzoek dat aandacht schenkt aan de beschermende factoren van ouders kan mogelijks beter zicht bieden op geslachtsverschillen.

Onze bevindingen hebben zowel implicaties voor toekomstig onderzoek als voor de praktijk. Met betrekking tot toekomstig onderzoek merken we op dat tot nu toe de meeste studies over opvoeding voornamelijk aandacht besteedden aan de rol van de moeder. Dit komt omdat moeders meestal de verzorgende rol op zich namen, terwijl vaders de kostwinners waren. Meer en meer nemen vaders echter opvoedingstaken op zich (Lamb, 2010). Onze studie toont aan dat ook vaders depressieve symptomen ervaren die -net zoals bij moeders- een gelijkaardige invloed hebben op de communicatie tussen ouder en kind. Onderzoek moet om die reden zowel het vaderals het moederperspectief integreren. Bovendien kan het interessant zijn om diepgaander te onderzoeken of actor- en partnereffecten voor vaders en moeders ook gevonden worden met andere stressoren (bv. financiële stress) en andere uitkomstvariabelen, zoals welbepaalde opvoedingsgedragingen.

Meer praktijkgericht toont ons onderzoek aan dat zelfs milde vormen van depressieve gevoelens een impact hebben op de ouder-kind communicatie van de partner. Het verminderen van deze depressieve gevoelens kan een 
positieve impact hebben op de communicatie met het kind. Wanneer ouders hulp of ondersteuning zoeken met betrekking tot opvoedingsgerelateerde thema's, is het dan ook voor begeleiders van belang dat ze niet alleen maar aandacht besteden aan de opvoedingsgedragingen van de ouders en de ouder-kind relatie, maar ook aan de mogelijke symptomen van stress en depressieve gevoelens die bij ouders aanwezig zijn. Het is met andere woorden noodzakelijk om een integraal beeld te krijgen van de ouder. Ouder zijn is immers meer dan alleen maar opvoeden. Daarenboven blijkt uit ons onderzoek dat de depressieve gevoelens van de ene ouder een invloed hebben op de ouder-kind relatie van de andere ouder, waardoor het aangewezen lijkt om beide ouders zoveel mogelijk te betrekken in het hulpverleningsproces. Het is niet omdat de ene ouder depressieve symptomen vertoont dat de andere oudere die ook vertoont, maar het is wel duidelijk dat de depressieve symptomen van een ouder een invloed heeft op de andere familieleden. Daarom kan het belangrijk zijn om ouders niet alleen te leren omgaan met de eigen depressieve symptomen, maar ook om hen bepaalde vaardigheden aan te leren zodat ze oog hebben voor en kunnen omgaan met de depressieve symptomen van de andere ouder. 


\section{REFERENTIES}

Ackard, D., Neumark-Sztainer, D., Story, M., \& Perry, C. (2006). Parent-child connectedness and behavioral and emotional health among adolescents. American Journal of Preventive Medicine, 30(1), 59-66.

American Psychiatric Association. (2000). Diagnostic and statistical manual of mental disorders (4th ed., text revision). Washington, DC: Author.

Baumrind, D. (1991). The influence of parenting style on adolescent competence and substance use. Journal of Early Adolescence, 11(1), 56-95.

Belsky, J. (1984). The determinants of parenting. A process model. Child Development, 55(1), 83-96.

Bronfenbrenner, U. (1989). Ecological systems theory. Annual Child Development, 6, 187249.

Brown, T. (2006). Confirmatory factor analysis for applied research. New York: The Guilford Press.

Coiro, M. J., \& Emery, R. E. (1998). Do marriage problems affect fathering more than mothering? A quantitative and qualitative review. Clinical Child and Family Psychology Review, 1(1), 23-40.

Crnic, K., Gaze, C., \& Hoffman, C. (2005). Cumulative parenting stress across the preschool period: Relations to maternal parenting and child behaviour at age 5 . Infant and Child Development, 14(2), 117132.
Crnic, K., \& Low, C. (2002). Everyday stresses and parenting. In M. Bornstein (Ed.), Handbook of Parenting: Practical Issues in Parenting (2nd ed., Vol. 5, pp. 243-267). Mahway, NJ: Lawrance Erlbaum Associates.

Cummings, E. M., Goeke-Morey, M. C., \& Raymond, J. (2004). Fathers in family context: Effects of marital quality and marital conflict. In M. Lamb (Ed.), The role of the father in child development (4th ed., pp. 196-221). New York: Wley.

Cummings, E. M., Merrilees, C. E., \& George, M. W. (2010). Fathers, marriages and families: Revisiting and updating the framework for fathering in family context. In M. Lamb (Ed.), The role of the father in child development (5th ed., pp. 154-176). Hoboken, New Jersey: Wiley and Sons, Inc.

Goodman, S. (2007). Depression in mothers. Annual Review of Clinical Psychology, 3, 107-135.

Goodman, S., \& Gotlib, I. (1999). Risk for psychopathology in the children of depressed mothers: A developmental model for understanding mechanisms of transmission. Psychological Review, 106(3), 458-490.

Goodman, S., Rouse, M., Connell, A. M., Broth, M., Hall, J., \& Heyward, D. (2011). Maternal depression and child psychopathology: A meta-analytic review. Clinical Child and Family Psychology Review(14), 1-27.

Jackson, S., Bijstra, J., Oostra, L., \& Bosma, H. (1998). Adolescents' perceptions of communication with parents relative to specific aspects of relationships with parents and personal development. Journal of Adolescence, 21(3), 305-322. 
Kenny, D., Kashy, D., \& Cook, W. (2006). Dyadic data analysis. New York: The Guilford Press.

Kenny, D. A., \& Ledermann, T. (2010). Detecting, measuring, and testing dyadic patterns in the actor-partner interdependence model. Journal of Family Psychology, 24(3), 359-366.

Krishnakumar, A., \& Buehler, C. (2000). Interparental conflict and parenting behaviors: A meta-analytic review. Family Relations, 49(1), 25-44.

Lamb, M. (2010). How do father influence children's development? Let me count the ways. In M. Lamb (Ed.), The role of the father in child development (5th ed., pp. 126). Hoboken, New Jersey: Wiley \& Sons, Inc.

Nelson, J. A., O'Brien, M., Blankson, A. N., Calkins, S. D., \& Keane, S. P. (2009). Family stress and parental responses to children's negative emotions: Tests of the spillover, crossover, and compensatory hypotheses. Journal of Family Psychology, 23(5), 671679.

Mitchell, S. J., See, H. M., Tarkow, A. K. H., Cabrera, N., McFadden, K. E., \& Shannon, J. D. (2007). Conducting studies with fathers: Challenges and opportunities. Applied Developmental Science, 11(4), 239-244.

Ohan, J., Leung, D., \& Johnston, C. (2000). The parenting sense of competence scale: Evidence of a stable factor structure and validity. Canedian Journal of Behavioural Science, 32:4,251-261.
Phares, V., Duhig, A., \& Watkins, M. (2002). Family context: Fathers and other supports. In S. H. Goodman \& I. Gotlib (Eds.), Children of depressed parents: Mechanisms of risk and implication for treatment. Washington, D.: American Psychological Association.

Ponnet, K., Mortelmans, D., Wouters, E., Van Leeuwen, K., Bastaits, K., \& Pasteels, I. (2012). Parenting stress and marital relationship as determinants of mothers' and fathers' parenting. Personal relationships. Early View.

Radloff, L. (1977). The CES-D scale: A selfreport depression scale for research in the general population. Applied Psychological Measurement, 1, 385-401.

Rehman, U., Gollan, J., \& Mortimer, A. (2008). The marital context of depression: Research, limitations, and new directions. Clinical Psychology Review, 28(2), 179-198.

Reitz, E., Dekovic, M., Meijer, A., \& Engels, R. (2006). Longitudinal relations among parenting, best friends, and early adolescent problem behavior - Testing bidirectional effects. Journal of Early Adolescence, 26(3), 272-295.

Riesch, S., Anderson, L., \& Krueger, H. (2006). Parent-child communication processes: Preventing children's health-risk behavior. Journal for Specialists in Pediatric Nursing, 11(1), 41-56

Seginer, R., Vermulst, A., \& Gerris, J. (2002). Bringing up adolescent children: A longitudinal study of parents' child-rearing stress. International Journal of Behavioral Development, 26(5), 410-422. 
2013, Vol 3 - Nr 1

Van de Velde, S., Bracke, P., \& Levecque, K. (2010). Gender differences in depression in 23 European countries. Cross-national variation in the gender gap in depression. Social Science \& Medicine, 71(2), 305-313.

Wilson, S., \& Durbin, C. (2010). Effects of paternal depression on fathers' parenting behaviors: A meta-analytic review. Clinical Psychology Review, 30(2), 167-180. 


\section{ENGLISH ABSTRACT}

This study examines how parenting stress and depressive symptoms experienced by mothers and fathers influence their own (actor effects) and the partner's (partner effects) parent-child communication. Based on the Actor-Partner Interdependence Model, data from 196 families were analyzed, with both parents rating their parenting stress and depressive feelings, and parents as well as children rating the open parent-child communication.

Actor effects were found between parenting stress and open parent-child communication, while partner effects were prominent between depressive symptoms and open parent-child communication. The results provide no evidence for gender differences in the strength of the pathways to open parent-child communication. Implications for future research and practitioners are provided.

Keywords: Dyadic approach, parenting stress, depressive symptoms, communication 